\title{
Melatonin Improves Outcomes of Heatstroke in Mice by Reducing Brain Inflammation and Oxidative Damage and Multiple Organ Dysfunction
}

\author{
Yu-Feng Tian, ${ }^{1,2}$ Cheng-Hsien Lin, ${ }^{3,4}$ Shu-Fen Hsu, ${ }^{3}$ and Mao-Tsun Lin ${ }^{4}$ \\ ${ }^{1}$ Division of General Surgery, Department of Surgery, Chi Mei Medical Center, Tainan 710, Taiwan \\ ${ }^{2}$ Department of Health and Nutrition, Chia Nan University of Pharmacy and Science, Tainan 717, Taiwan \\ ${ }^{3}$ Department of Nursing, Shu-Zen Junior College of Medicine and Management, Kaohsiung 821, Taiwan \\ ${ }^{4}$ Department of Medical Research, Chi Mei Medical Center, Tainan 710, Taiwan
}

Correspondence should be addressed to Mao-Tsun Lin; 891201@mail.chimei.org.tw

Received 8 October 2013; Accepted 21 November 2013

Academic Editor: Francesco Marotta

Copyright (C) 2013 Yu-Feng Tian et al. This is an open access article distributed under the Creative Commons Attribution License, which permits unrestricted use, distribution, and reproduction in any medium, provided the original work is properly cited.

\begin{abstract}
We report here that when untreated mice underwent heat stress, they displayed thermoregulatory deficit (e.g., animals display hypothermia during room temperature exposure), brain (or hypothalamic) inflammation, ischemia, oxidative damage, hypothalamic-pituitary-adrenal axis impairment (e.g., decreased plasma levels of both adrenocorticotrophic hormone and corticosterone during heat stress), multiple organ dysfunction or failure, and lethality. Melatonin therapy significantly reduced the thermoregulatory deficit, brain inflammation, ischemia, oxidative damage, hypothalamic-pituitary-adrenal axis impairment, multiple organ dysfunction, and lethality caused by heat stroke. Our data indicate that melatonin may improve outcomes of heat stroke by reducing brain inflammation, oxidative damage, and multiple organ dysfunction.
\end{abstract}

\section{Introduction}

Melatonin, the main product of the pineal gland, is found in high concentrations in other body fluids and tissues [1, $2]$ and possesses anti-inflammatory and antioxidant actions [3-6]. We have evaluated the prophylactic [7] as well as the therapeutic [8] effect of melatonin in heatstroke rats under general anesthesia and showed the therapeutic effects of melatonin on heatstroke-induced multiple organ dysfunction syndrome. According to a more recent review [9], the ischemic and oxidative damage to the hypothalamus during heatstroke may cause multiple organ dysfunction or failure through hypothalamic-pituitary-adrenal (HPA) axis mechanisms. Studies are warranted to know whether the heatstroke-induced brain (or hypothalamic) inflammation and damage, thermoregulatory deficits, and multiple organ dysfunction can be affected by melatonin therapy in an unanesthetized and unrestrained mouse model [10-12].

To deal with the hypothesis, we assessed the temporal profiles of cellular markers of ischemia (e.g., glutamate and lactate/pyruvate ratio), damage (e.g., glycerol), inflammation (e.g., tumor necrosis factor-alpha (TNF- $\alpha$ ), interleukin-1 (IL$1 \beta)$, IL-10, and myeloperoxidase (MPO) activity), and oxidative damage (e.g., prooxidant enzymes (e.g., lipid peroxidation and glutathione oxidation), anti-oxidant defenses (e.g., glutathione peroxidase $\left(\mathrm{GP}_{x}\right)$, and glutathione reductase (GR), oxidant radicals, nitric oxide metabolites $\left(\mathrm{NO}_{x}\right)$, and dihydroxybenzoic acid (DHBA)) in the hypothalamus that occurred after heat regimen in mice treated with or without melatonin therapy. In addition, the influence of melatonin therapy on the heatstroke-induced thermoregulatory deficits as well as increased plasma levels of multiple organ dysfunction or failure [10-12] was assessed.

\section{Materials and Methods}

2.1. Mice. Present studies were performed in male ICR mice (29-37 g), whose stock originated from the Institute of Cancer Research of the National Institutes of Health in the 
USA. They were purchased from the National Animal Center (Taipei, Taiwan) and kept under a 12-hour light-dark cycle at controlled temperature $\left(21 \pm 2^{\circ} \mathrm{C}\right)$ with free access to food and tap water.

2.2. Murine Model of Heatstroke. Institute of Cancer Research male mice 8 to 10 weeks old were exposed to whole body heating $\left(\mathrm{WBH} ; 41.2^{\circ} \mathrm{C}\right.$; relative humidity $50 \%-55 \%$; $\left.1 \mathrm{~h}\right)$ in an environment-controlled chamber [10-12]. The heat-stressed mice were returned to the normal room temperature $\left(26^{\circ} \mathrm{C}\right)$ after the end of the heat exposure. Mice that survived to day 4 of heat treatment were considered survivors, and the data were used for analysis of the results. Core temperatures were measured every $1 \mathrm{~min}$ with a copper constant thermocouple inserted into the rectum and connected to a thermometer (HR1300; Yokogawa, Tokyo, Japan). Before the start of thermal experiments, mice were housed at an ambient temperature $\left(26^{\circ} \mathrm{C}\right)$ below the neutral zone for this species. After 1-hour heating period, animals were properly fed and hydrated. In separate experiments, $4 \mathrm{~h}$ post-WBH, animals were sacrificed and their brains and blood were obtained for biochemical verification [10-12].

2.3. Experimental Groups. Three hundred mice were randomly divided into 3 major groups: (a) nonheated mice treated with vehicle solution $(n=60)$ : these groups of animals were s.c. injected with one dose of $0.2 \mathrm{~mL}$ of $0.25 \%$ ethanol-saline [13] immediately post-WBH; (b) heated mice treated with vehicle solution $(n=60)$; and (c) heated mice treated with melatonin (N-acetyl-5methoxytryptamine) $(0.2 \mathrm{mg} / \mathrm{kg}, 1 \mathrm{mg} / \mathrm{kg}$, or $5 \mathrm{mg} / \mathrm{kg})[14]$ immediately post-WBH $(n=180)$.

In Experiment 1, effects of heat exposure on body core temperature and \% survival of different groups of mice were assessed $(n=60)$.

In Experiment 2, effects of heat exposure on cellular ischemia and damage markers in brain (or hypothalamus) of different groups of mice were measured $(n=60)$.

In Experiment 3, effects of heat exposure on inflammatory mediators in brain (or hypothalamus) of different groups of mice were measured $(n=60)$.

In Experiment 4, effects of heat exposure on oxidative stress markers in brain (or hypothalamus) of different groups of mice were measured $(n=60)$.

In Experiment 5, effects of heat exposure on serum levels of multiple organ dysfunction indicators, ACTH, and corticosterone of different groups were measured $(n=60)$.

2.4. Extracellular Levels of Glutamate, Lactate-to-Pyruvate Ratio, Glycerol, Nitric Oxide, and Hydroxyl Radicals in the Hypothalamus. Hypothalamic samples were homogenized in $0.05 \mathrm{M}$ phosphate buffer at $\mathrm{pH} 7.0$ and then centrifuged at $4000 \times \mathrm{g}$ for $20 \mathrm{~min}$ at $4^{\circ} \mathrm{C}$. The supernatants were used for the determination of cellular levels of glutamate, lactate-topyruvate ratio, glycerol, nitric oxide, and hydroxyl radicals. The dialysis probe ( $4 \mathrm{~nm}$ in length c CMA/12; Carnegie Medicine, Stockholm, Sweden) was put into the supernatants to obtain the dialysates.
The nitric oxide $\left(\mathrm{NO}_{x}{ }^{-}\right)$concentration in the dialysates of hypothalamus was measured with the Eicom ENO-20 $\mathrm{NO}_{x}{ }^{-}$analysis system (Eicom, Kyoto) [15]. In the Eicom ENO-20 $\mathrm{NO}_{x}{ }^{-}$analysis system, after the $\mathrm{NO}_{2}{ }^{-}$and $\mathrm{NO}_{3}{ }^{-}$in the sample have been separated by the column, the $\mathrm{NO}_{2}{ }^{-}$reacts in the acidic solution with the primary aromatic amine to produce an azo compound. Following this, the addition of aromatic amines to the azo compound results in a coupling that produces a diazo compound, and the absorbance rate of the red color in this compound is then measured. For measurement of glutamate, lactate-to-pyruvate ratio, and glycerol, the dialysates were injected onto a CMA600 microdialysis analyzer (Carnegie Medicine, Stockholm, Sweden). The concentrations of hydroxyl radicals were measured by a modified procedure based on the hydroxylation of sodium salicylates by hydroxyl radicals, leading to the production of 2,3-dihydroxybenzoic acid and 2,5-dihydroxybenzoic acid [16].

2.5. Determination of Lipid Peroxidation. Lipid peroxidation was assessed by measuring the levels of malondialdehyde (MDA) with 2-thiobarbituric acid (TBA) to form a chromophore absorbing at $532 \mathrm{~nm}$ [17]. About $0.1 \mathrm{~g}$ of tissue was homogenized with $1.5 \mathrm{~mL}$ of $0.1 \mathrm{M}$ phosphate buffer at $\mathrm{pH} 3.5$. The reaction mixture $(0.2 \mathrm{~mL}$ of sample, $1.5 \mathrm{~mL}$ of $20 \%$ acetic acid, $0.2 \mathrm{~mL}$ of $8.1 \%$ sodium dodecyl sulfate, and $1.5 \mathrm{~mL}$ of aqueous solution of $0.8 \% \mathrm{TBA}$, up to $4 \mathrm{~mL}$ with distilled water) was heated to $95^{\circ} \mathrm{C}$ for $1 \mathrm{~h}$, and then $5 \mathrm{~mL}$ of $\mathrm{N}$-butanol and pyridine $(15: 1 \mathrm{vol} / \mathrm{vol})$ was added. The mixture was vortexed vigorously and centrifuged at $1500 \mathrm{~g}$ for $10 \mathrm{~min}$, and the absorbance of the organic phase was measured at $532 \mathrm{~nm}$. The values were expressed as nanomoles of TBA-reactive substances (MDA equivalent) per milligram of protein.

2.6. Quantification of Total and Oxidized Glutathione. Tissues were homogenized in 5\% 5-sulfosalicylic acid $(1: 10 \mathrm{wt} / \mathrm{vol})$ at $0^{\circ} \mathrm{C}$, and the supernatants were used for analysis of total and oxidized glutathione. Total glutathione (reduced-form glutathione $(\mathrm{GSH})+$ oxidized-form glutathione (GSSG)) was analyzed according to the Tietze method [18], and GSSG was determined as described by Griffith [19]. The recycling assay for total glutathione is oxidized by 5,5-Dithiobis (2 acid) (DTNB) to give GSSG with stoichiometric formation of 5-thio-2-nitrobenzoic acid. GSSG is reduced to GSH by the action of the highly specific glutathione reductase (GR) and nicotinamide adenine dinucleotide phosphate (reduced form; NADPH). The rate of 5thio-2-nitrobenzoic acid formation is followed at $412 \mathrm{~nm}$ and is proportional to the sum of GSH and GSSG present.

2.7. Determination of Glutathione Peroxidase $\left(G P_{x}\right)$ and Glutathione Reductase (GR) Activity. Tissues were homogenized in $0.05 \mathrm{M}$ phosphate buffer, pH7.0 and then centrifuged at $4000 \times \mathrm{g}$ for $20 \mathrm{~min}$ at $4^{\circ} \mathrm{C}$. The supernatants were used for $\mathrm{GP}_{x}$ and GR activity assay. The GP $x$ and GR activities were performed with a commercial $\mathrm{GP}_{x}$ assay kit (Sigma, USA) and a GP assay kit (Sigma, USA), respectively. One unit of $\mathrm{GP}_{x}$ and GR activity was defined as the amount of sample 
TABLE 1: Effects of heat exposure on body core temperatures of different groups of mice.

\begin{tabular}{lcr}
\hline Treatment groups & Core temperature $\left({ }^{\circ} \mathrm{C}\right)$ & $P$ values \\
\hline (1) Nonheated mice untreated & $37.2 \pm 0.3$ & $33.2 \pm 0.2$ \\
(2) Heated mice treated with vehicle saline & $33.5 \pm 0.3$ & ${ }^{\mathrm{a}} P<0.01$ \\
(3) Heated mice treated with melatonin $0.2 \mathrm{mg} / \mathrm{kg}$ & $36.3 \pm 0.3$ & ${ }^{\mathrm{a}} P<0.01$ \\
(4) Heated mice treated with melatonin $1 \mathrm{mg} / \mathrm{kg}$ & $37.4 \pm 0.4$ & ${ }^{\mathrm{b}} P<0.01$ \\
(5) Heated mice treated with melatonin $5 \mathrm{mg} / \mathrm{kg}$ & ${ }^{\mathrm{b}} P<0.01$ \\
\hline
\end{tabular}

Core temperatures were measured 4 hours after whole body heating for heated groups or the equivalent time period for non-heated groups. ${ }^{a}$ Compared with non-heated groups; ${ }^{\mathrm{b}}$ Compared with group 2. Data are means \pm S.E.M. of 12 mice per group.

required to oxidize $1 \mathrm{mmol}$ of $\mathrm{NADPH}$ per minute based on the molecular absorbance of $6.22 \times 10^{6}$ for NADPH.

2.8. Myeloperoxidase Activity. MPO activity, an indicator of polymorphonuclear leukocyte accumulation, was determined in the hypothalamus as described previously [20] at 4 hours after heat stress. MPO activity was defined as the quantity of enzyme degrading $1 \mu \mathrm{mol}$ of peroxide $/ \mathrm{min}$ at $37^{\circ} \mathrm{C}$ and was expressed in milliunits/gram of wet tissue.

2.9. Determination of Cytokines in the Hypothalamus. The hypothalamic samples were prepared according to previous reports [21]. The tissues were homogenized in five volumes of ice-cold Ripa buffer. The homogenates were incubated on ice for $30 \mathrm{~min}$ and then centrifuged $\left(15,000 \times \mathrm{g}, 30 \mathrm{~min}, 4^{\circ} \mathrm{C}\right)$ twice. The concentrations of these cytokines in the supernatants were determined by commercially available ELISA kits ( R \& D Systems, Minneapolis, MN, USA) according to the manufacturer's instructions. Optical densities were read on a plate reader set at $450 \mathrm{~nm}$ for these cytokines. The concentrations of these cytokines in the samples were calculated from the standard curve multiplied by the dilution factor and were expressed as $\mathrm{pg} / \mathrm{g}$.

2.10. Quantification of Multiple Organ Dysfunction and Injury. Creatinine, blood urea nitrogen (BUN), alanine aminotransferase (ALT), aspartate aminotransferase (AST), and alkaline phosphatase (ALP) were estimated in blood samples collected 4 hours after the start of heat stress or the equivalent time point for the nonheated animals. The serum levels of creatinine, BUN, ALT, AST, and ALP were determined by spectrophotometry (HITACHI 7600, Tokyo, Japan).

2.11. Plasma Assessment of Corticosterone and Adrenocorticotrophic Hormone (ACTH). Plasma corticosterone and ACTH were assessed using corticosterone Double Antibody RIA kit (MP Biomedicals, Solon, Oh, USA) and ACTH (Rat, Mouse)-RIA kit (Phoenix Pharmaceuticals, Burlingame, CA, USA), respectively. All analyses were performed according to manufacturer's instructions.

2.12. Statistical Analysis. All values in the tables and text are expressed as mean \pm S.E.M. of $n$ observations, where $n$ represents the number of animals studied. Statistical evaluation was performed by using analysis of variance (ANOVA) followed by a multiple-comparison test (Scheffe's test). A $P$ value of less than 0.05 was considered to be statistically significant.

\section{Results}

3.1. Melatonin Prevents Heat-Induced Hypothermia and Lethality. As summarized in Table 1, the body core temperature values of heated mice were significantly lower than those of nonheated mice kept at a normal ambient temperature $\left(26^{\circ} \mathrm{C}\right)\left(33.2 \pm 0.2^{\circ} \mathrm{C}\right.$ and $37.2 \pm 0.3^{\circ} \mathrm{C}$, resp. $)(P<0.001)$. Additionally, the fraction survival of heated mice was significantly lower than those of nonheated mice (1/12 and $12 / 12$, resp.) $(P<0.001)$ (Figure 1$)$. The heat-induced hypothermia and lethality were significantly reduced by melatonin therapy (Table 1 and Figure 1).

3.2. Melatonin Reduces Heat-Induced Increased Levels of Glutamate, Lactate-to-Pyruvate Ratio, Glycerol, Nitrite (NO), and Dihydroxybenzoic Acid (DHBAs) in the Hypothalamus. Table 2 summarizes the effects of heat exposure on cellular levels of glutamate, lactate-to-pyruvate ratio, glycerol, nitrite, and DHBA in the hypothalamus in different groups of mice. As compared with nonheated mice, the heated mice had higher levels of glutamate, lactate-to-pyruvate ratio, glycerol, nitrite, and DHBA in the hypothalamus $(P<0.05)$. The heatinduced increased levels of glutamate, lactate-to-pyruvate ratio, glycerol, nitrite, and DHBA in the hypothalamus were all significantly and dose-dependently reduced by melatonin (0.2-5.0 mg/kg).

3.3. Melatonin Attenuates Heat-Induced Increased Levels of TNF- $\alpha$, IL-1 $\beta$, and MPO but Increases Production of IL-10 in the Hypothalamus. As shown in Table 3, hypothalamic levels of TNF- $\alpha, \mathrm{IL}-1 \beta$, and MPO were all increased in heated mice. Again, heat-induced overproduction of TNF- $\alpha$, IL- $1 \beta$, and MPO was significantly and dose-dependently reduced by melatonin therapy $(0.2-5.0 \mathrm{mg} / \mathrm{kg})(P<0.05)$. In contrast, hypothalamic levels of IL-10 were significantly and dosedependently increased by melatonin treatment in heated mice.

3.4. Melatonin Decreases Heat-Induced Hypothalamic Oxidative Stress. As shown in Table 4, the hypothalamic levels of both MDA and GSSG/GSH in heated mice were significantly higher than those of nonheated mice. In contrast, the hypothalamic levels of GP, GR of heated mice were 
TABLE 2: Effect of heat exposure on hypothalamic levels of various parameters in different groups of mice.

\begin{tabular}{|c|c|c|c|c|c|}
\hline Treatment groups & $\begin{array}{c}\text { Glutamate } \\
\text { (\% of baseline) }\end{array}$ & $\begin{array}{c}\text { Lactate/pyruvate } \\
\text { ratio }\end{array}$ & $\begin{array}{c}\text { Glycerol } \\
\text { (\% of baseline) }\end{array}$ & $\begin{array}{c}\text { Nitric oxide } \\
(\mu \mathrm{M})\end{array}$ & $\begin{array}{c}2,3-\mathrm{DHBA} \\
\text { (\% of baseline) }\end{array}$ \\
\hline (1) Non-heated mice & $100 \pm 6$ & $10 \pm 3$ & $100 \pm 5$ & $16 \pm 2$ & $100 \pm 5$ \\
\hline $\begin{array}{l}\text { (2) Heated mice treated } \\
\text { with vehicle solution }\end{array}$ & $207 \pm 11^{\mathrm{a}}$ & $219 \pm 15^{\mathrm{a}}$ & $173 \pm 7^{\mathrm{a}}$ & $99 \pm 11^{\mathrm{a}}$ & $151 \pm 8^{\mathrm{a}}$ \\
\hline $\begin{array}{l}\text { (3) Heated mice treated } \\
\text { with melatonin } \\
0.2 \mathrm{mg} / \mathrm{kg}\end{array}$ & $214 \pm 12$ & $206 \pm 14$ & $214 \pm 11$ & $106 \pm 10$ & $165 \pm 7$ \\
\hline $\begin{array}{l}\text { (4) Heated mice treated } \\
\text { with melatonin } 1 \mathrm{mg} / \mathrm{kg}\end{array}$ & $141 \pm 8^{\mathrm{b}}$ & $87 \pm 5^{\mathrm{b}}$ & $135 \pm 5^{\mathrm{b}}$ & $61 \pm 4^{\mathrm{b}}$ & $118 \pm 5^{\mathrm{b}}$ \\
\hline $\begin{array}{l}\text { (5) Heated mice treated } \\
\text { with melatonin } 5 \mathrm{mg} / \mathrm{kg}\end{array}$ & $106 \pm 5^{\mathrm{b}}$ & $10 \pm 2^{\mathrm{b}}$ & $102 \pm 4^{\mathrm{b}}$ & $15 \pm 2^{\mathrm{b}}$ & $99 \pm 6^{\mathrm{b}}$ \\
\hline
\end{tabular}

Samples were measured 4 hours after whole body heating or the equivalent time period for non-heated groups. ${ }^{a}$ Compared with non-heated groups $(P<0.05)$;

${ }^{\mathrm{b}}$ Compared with group $2(P<0.05)$. Data are means \pm S.E.M. of 12 mice per group.

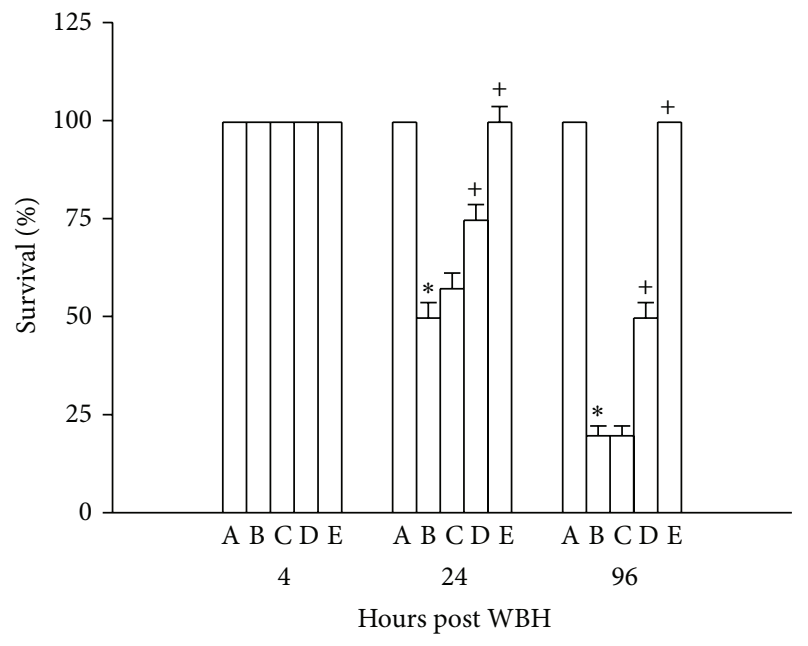

FIGURE 1: Percent survival values for nonheated mice untreated (A), heated mice treated with vehicle solution (B), heated mice treated with melatonin $(0.2 \mathrm{mg} / \mathrm{kg})(\mathrm{C})$, heated mice treated with melatonin $(1 \mathrm{mg} / \mathrm{kg})(\mathrm{D})$, and heated mice treated with melatonin $(5 \mathrm{mg} / \mathrm{kg})(\mathrm{E})$ 4-96 hours after whole body heating (WBH). Data are expressed as means \pm S.E.M. for 12 mice per group. ${ }^{*} P<0.05$ compared with nonheated mice untreated mice; ${ }^{+} P<0.05$ compared with heated mice treated with vehicle solution.

significantly higher than those of nonheated mice $(P<0.05)$. The heat-induced increased levels of MDA and GSSG/GSH as well as the decreased levels of GP, GR in the hypothalamus were significantly and dose-dependently reduced by melatonin therapy $(0.2-5.0 \mathrm{mg} / \mathrm{kg})(P<0.05)$.

\subsection{Melatonin Attenuates Heat-Induced Increased Plasma} Levels of Multiple Organ Injury Markers. The plasma levels of BUN, creatinine, ALT, AST, and AP in heated mice were all significantly higher than those of nonheated mice (Table 5). The heat-induced increased plasma levels of these parameters were all significantly and dose-dependently reduced by melatonin treatment $(0.2-5.0 \mathrm{mg} / \mathrm{kg})(P<0.05)$.
3.6. Melatonin Enhances Heat-Induced Increased Plasma Levels of Both ACTH and Corticosterone. As shown in Table 6, the plasma levels of both ACTH and corticosterone in heated mice were significantly higher than those of nonheated controls $(P<0.05)$. The heat-induced increased plasma levels of both ACTH and corticosterone were all significantly enhanced by melatonin therapy $(P<0.05$; Table 6$)$.

\section{Discussion}

According to Chatterjee et al. $[10,11]$, heat-treated mice display body core temperatures of $>40^{\circ} \mathrm{C}$ immediately after the termination of $\mathrm{WBH}$ and profound hypothermia at +4 , +6 , and $+20 \mathrm{~h}$ after. This is confirmed by the present results. We further demonstrate that heat-induced hypothermia in mice can be significantly and dose-dependently prevented by melatonin therapy. However, the contention is not consistent with the findings of Leon et al. [22], who reported on mice exposed to an ambient temperature of $\sim 39.5^{\circ} \mathrm{C}$ until a maximal core temperature of $42.7^{\circ} \mathrm{C}$ was attained. During their recovery, the mice had hypothermia $\left(29.3^{\circ} \mathrm{C}\right)$ and, after $24 \mathrm{~h}$ of recovery, a fever-like elevation $\left(37.8^{\circ} \mathrm{C}\right)$.

The hypothalamus is believed to be involved in regulating homeostasis, motivation, and emotional behavior; these functions are mediated through hypothalamic control of autonomic and endocrine activity [23]. The hypothalamus allows the output of pituitary hormones to response to changes in the autonomic nervous system activity and to the needs of temperature regulation, water balance, and energy requirements. Heat exposure is a stimulus that triggers biological stress reactions [24]. The hypothalamo-pituitaryadrenocortical (HPA) axis is also mobilized, as suggested by the increase in c-fos-positive cells [25] and c-fos mRNA content [26] in the hypothalamic paraventricular nucleus, as well as the increase in blood adrenocorticotrophichormone (ACTH) and corticosterone concentrations [27, 28]. Decreased heat tolerance has been associated with HPA axis impairment [29]. More than half a century ago, thermal injury to the thermoregulatory centers of the hypothalamus 
TABLE 3: Effects of heat exposure on hypothalamic levels of various parameters in different groups of mice.

\begin{tabular}{lcccc}
\hline Treatment groups & TNF- $\alpha$ (pg/g) & IL-1 $\beta$ (pg/g) & IL-10 (pg/g) & MPO activity (pg/wet tissue) \\
\hline (1) Non-heated mice & $10 \pm 3$ & $8 \pm 2$ & $5 \pm 2$ & $51 \pm 8$ \\
(2) Heated mice treated with vehicle solution & $208 \pm 18^{\mathrm{a}}$ & $426 \pm 51^{\mathrm{a}}$ & $6 \pm 3$ & $448 \pm 14$ \\
(3) Heated mice treated with melatonin $0.2 \mathrm{mg} / \mathrm{kg}$ & $224 \pm 21$ & $453 \pm 56$ & $4 \pm 2$ & $507 \pm 17$ \\
(4) Heated mice treated with melatonin $1 \mathrm{mg} / \mathrm{kg}$ & $88 \pm 8^{\mathrm{b}}$ & $190 \pm 18^{\mathrm{b}}$ & $212 \pm 22^{\mathrm{b}}$ & $144 \pm 9^{\mathrm{b}}$ \\
(5) Heated mice treated with melatonin $5 \mathrm{mg} / \mathrm{kg}$ & $9 \pm 3^{\mathrm{b}}$ & $8 \pm 3^{\mathrm{b}}$ & $256 \pm 30^{\mathrm{b}}$ & $51 \pm 11^{\mathrm{b}}$ \\
\hline
\end{tabular}

Samples were measured 4 hours after whole body heating for non-heated groups. ${ }^{\mathrm{a}}$ Compared with non-heated groups $(P<0.05) ;{ }^{\mathrm{b}}$ Compared with group 2 $(P<0.05)$. Data are means \pm S.E.M. of 12 mice per group.

TABLE 4: Effects of heat exposure on hypothalamic levels of various parameters in different groups of mice.

\begin{tabular}{|c|c|c|c|c|}
\hline Treatment groups & MDA ( $\mathrm{n} \mathrm{mol} / \mathrm{mg}$ protein) & GSSG/GSH & GP (m U/mg protein) & GR ( $\mathrm{m} \mathrm{U} / \mathrm{mg}$ protein) \\
\hline (1) Non-heated mice & $6.9 \pm 0.6$ & $0.55 \pm 0.16$ & $318 \pm 39$ & $182 \pm 18$ \\
\hline (2) Heated mice treated with vehicle solution & $12 \pm 2^{\mathrm{a}}$ & $2.24 \pm 0.38^{\mathrm{a}}$ & $87 \pm 18^{\mathrm{a}}$ & $76 \pm 12^{\mathrm{a}}$ \\
\hline (3) Heated mice treated with melatonin $0.2 \mathrm{mg} / \mathrm{kg}$ & $11 \pm 1^{\mathrm{a}}$ & $2.42 \pm 0.3^{\mathrm{b}}$ & $76 \pm 15$ & $72 \pm 11$ \\
\hline (4) Heated mice treated with melatonin $1 \mathrm{mg} / \mathrm{kg}$ & $6 \pm 1^{b}$ & $0.98 \pm 0.21^{b}$ & $185 \pm 25^{\mathrm{b}}$ & $144 \pm 16^{\mathrm{b}}$ \\
\hline (5) Heated mice treated with melatonin $5 \mathrm{mg} / \mathrm{kg}$ & $4 \pm 1^{\mathrm{b}}$ & $0.42 \pm 0.15^{\mathrm{b}}$ & $369 \pm 41^{\mathrm{b}}$ & $192 \pm 19^{b}$ \\
\hline
\end{tabular}

Samples were measured 4 hours after whole body heating for non-heated groups. ${ }^{\mathrm{a}}$ Compared with non-heated groups $(P<0.05)$; ${ }^{\mathrm{b}}$ Compared with group 2 $(P<0.05)$. Data are means \pm S.E.M. of 12 mice per group.

was hypothesized to be the primary mechanism of mortality [30]. Indeed, according to a more recent review [9], ischemic and oxidative damage to the hypothalamus may be responsible for heatstroke. Severe heat stress increases cutaneous blood flow and metabolism and decreases splanchnic blood flow. Severe heat stress also decreases mean arterial pressure, increases intracranial pressure, and decreases cerebral perfusion pressure, all of which lead to cerebral ischemia and hypoxia. Compared with normothermic controls, rodents with heatstroke have higher values of cellular ischemia (e.g., glutamate and lactate-to-pyruvate ratio) and damage (e.g., glycerol) markers, prooxidant enzymes (e.g., lipid peroxidation and glutathione oxidation markers), proinflammatory cytokines (e.g., interleukin-1 $\beta$ and tumor necrosis factor$\alpha$ ), inducible nitric oxide-synthase-dependent nitric oxide and an indicator for the accumulation of polymorphonuclear leukocytes (e.g., myeloperoxidase activity) as well as neuronal damage (e.g., apoptosis and necrosis) in the hypothalamus after heat stroke. Hypothalamic values of antioxidant defenses (e.g., glutathione peroxidase and glutathione reductase), however, are lower. Melatonin therapy, in addition to attenuating heat-induced hypothermia (thermoregulatory deficits), significantly attenuates heat-induced inflammatory, ischemic and oxidative damage to the hypothalamus.

Furthermore, our present results demonstrated that melatonin therapy significantly enhanced HPA axis mechanisms (as reflected by increased plasma levels of both ACTH and corticosterone in response to heat stress), led to reduction of multiple organ dysfunction or failure (as reflected by decreased plasma levels of BUN, creatinine, ALT, AST, and ALP), and resulted in attenuation of lethality in heatstroke mice.

Our present results are consistent with many previous investigations. For example, melatonin improved the clinical outcome of the septic newborns as judged by measurement of sepsis-related serum parameters via reducing the serum levels of lipid peroxidation products [31]. A major brain metabolite of melatonin acts as a potent nitric oxide scavenger, inhibitor, and/or downregulator of neuronal and inducible nitric oxide synthase and as a mitochondrial metabolism modulator [32]. Melatonin protected against mitochondrial reactive oxygen species-mediated apoptosis in astrocytes [33] and isoproterenol-induced myocardial injury in the rat via its antioxidative mechanism [34]. In addition, melatonin protected the mitochondria from oxidative damage by preventing cardiolipin [35]. Melatonin also may attenuate peritonitis-induced lethality in conscious rats by exerting its antioxidant effect [36]. These observations prompted us to think that these multiple mitochondrial layers of protection provided by melatonin may be crucial for future therapeutic prevention and treatment of heatstroke.

Systemic inflammatory response syndrome is characterized by increased serum levels of TNF- $\alpha$, ICAM-1, E-selectin, IL-1 $\beta$, and IL-6 [37-40]. Increased levels of these systemic inflammatory response syndrome molecules have also been shown in patients [41] or rats [42]. In addition, the increased serum levels of these molecules during heatstroke in an anesthetized rat model could be reduced by melatonin treatment [7]. The present results further showed that the increased levels of some of these molecules in the hypothalamus in a mice could also be reduced by melatonin. Additionally, melatonin therapy increased the hypothalamic levels of IL10 in heatstroke, which was believed to be anti-inflammatory cytokine [43]. These results indicate that melatonin may reduce heat-induced activated inflammation by reducing the levels of these systemic inflammatory response molecules in the hypothalamus. It is known that melatonin intensifies the expression of protective heat shock proteins [44] and 
TABLE 5: Effect of heat exposure on serum levels of blood urea nitrogen (BUN), creatinine, alanine aminotransferase (ALT), aspartate aminotransferase (AST), and alkaline phosphate (AP) in different groups of mice.

\begin{tabular}{|c|c|c|c|c|c|}
\hline Treatment groups & $\mathrm{BUN}(\mathrm{mmol} / \mathrm{L})$ & Creatinine $(\mathrm{mmol} / \mathrm{L})$ & ALT (U/L) & $\mathrm{AST}(\mathrm{U} / \mathrm{L})$ & $\mathrm{AP}(\mathrm{U} / \mathrm{L})$ \\
\hline (1) Non-heated mice & $8 \pm 1$ & $27 \pm 2$ & $35 \pm 4$ & $111 \pm 8$ & $299 \pm 23$ \\
\hline (2) Heated mice treated with vehicle solution & $23 \pm 1^{\mathrm{a}}$ & $75 \pm 3^{\mathrm{a}}$ & $129 \pm 5^{\mathrm{a}}$ & $508 \pm 22^{\mathrm{a}}$ & $533 \pm 31^{\mathrm{a}}$ \\
\hline (3) Heated mice treated with melatonin $0.2 \mathrm{mg} / \mathrm{kg}$ & $21 \pm 2$ & $69 \pm 4$ & $130 \pm 6$ & $492 \pm 21$ & $505 \pm 28$ \\
\hline (4) Heated mice treated with melatonin $1 \mathrm{mg} / \mathrm{kg}$ & $15 \pm 2^{\mathrm{b}}$ & $52 \pm 2^{\mathrm{b}}$ & $85 \pm 3^{\mathrm{b}}$ & $274 \pm 16^{\mathrm{b}}$ & $395 \pm 19^{b}$ \\
\hline (5) Heated mice treated $5 \mathrm{mg} / \mathrm{kg}$ & $10 \pm 1^{\mathrm{b}}$ & $43 \pm 3^{\mathrm{b}}$ & $67 \pm 4^{\mathrm{b}}$ & $188 \pm 12^{\mathrm{b}}$ & $364 \pm 17^{\mathrm{b}}$ \\
\hline
\end{tabular}

Samples were measured 4 hours after whole body heating or the equivalent time period for non-heated groups. ${ }^{\text {a }}$ Compared with non-heated group $(P<0.05)$;

${ }^{\mathrm{b}}$ Compared with group $2(P<0.05)$. Data are means \pm S.E.M. of 12 mice per group.

TABLE 6: Effect of heat exposure on serum levels of adrenocorticotrophic-hormone (ACTH) and corticosterone in different groups of mice.

\begin{tabular}{lcc}
\hline Treatment groups & ACTH $\left(\mathrm{pg} \cdot \mathrm{mL}^{-1}\right)$ & ${\text { Corticosterone }\left(\mathrm{ng} \cdot \mathrm{mL}^{-1}\right)}$ \\
\hline (1) Non-heated mice & $392 \pm 98$ & $142 \pm 24$ \\
(2) Heated mice treated with vehicle solution & $984 \pm 127^{\mathrm{a}}$ & $505 \pm 26^{\mathrm{a}}$ \\
(3) Heated mice treated with melatonin $0.2 \mathrm{mg} / \mathrm{kg}$ & $1001 \pm 145$ & $518 \pm 28$ \\
(4) Heated mice treated with melatonin $1 \mathrm{mg} / \mathrm{kg}$ & $1668 \pm 162^{\mathrm{b}}$ & $719 \pm 31^{\mathrm{b}}$ \\
(5) Heated mice treated with melatonin $5 \mathrm{mg} / \mathrm{kg}$ & $2167 \pm 176^{\mathrm{b}}$ & $854 \pm 35^{\mathrm{b}}$ \\
\hline
\end{tabular}

Samples were measured 4 hours after whole body heating or the equivalent time period for non-heated groups. ${ }^{\text {a } C o m p a r e d ~ w i t h ~ n o n-h e a t e d ~ g r o u p ~}(P<0.05)$;

${ }^{\mathrm{b}}$ Compared with group $2(P<0.05)$. Data are means \pm S.E.M. of 12 mice per group.

that it enhances heat shock protein 27 expression [45] as well as having anti-inflammatory properties and antioxidant properties.

\section{Conclusion}

In summary, we report here that when untreated mice underwent heat stress, they displayed thermoregulatory deficit (e.g., animals display hypothermia during room temperature exposure), brain (or hypothalamic) inflammation, ischemia, and oxidative damage, HPA axis impairment, multiple organ dysfunction or failure, and lethality. Melatonin therapy may improve outcomes of heatstroke in mice by reducing brain inflammation and oxidative damage, and multiple organ dysfunction.

\section{Conflict of Interests}

The authors report no conflict of interests related to this study or the findings specified in this paper.

\section{Authors' Contribution}

Yu-Fong Tian and Cheng-Hsien Lin equally contributed to the work.

\section{Acknowledgments}

This study was supported in part by the National Science Council (Grant nos. NSC90-2314-B-384-006-MY2, NSC99-2314-B-384-004-MY3, and NSC101-2314-B-218-001MY3) and the Department of Health and Blessing, the Center of Excellence for Clinical Trial and Research in Neuroscience of the Republic of China (Grant no. DOH99-TD-B-111-003).

\section{References}

[1] A. Menendez-Pelaez and R. J. Reiter, "Distribution of melatonin in mammalian tissues: the relative importance of nuclear versus cytosolic localization," Journal of Pineal Research, vol. 15, no. 2, pp. 59-69, 1993.

[2] R. J. Reiter and D. Tan, "What constitutes a physiological concentration of melatonin?" Journal of Pineal Research, vol. 34, no. 1, pp. 79-80, 2003.

[3] A. Galano, D. X. Tan, and R. J. Reiter, "Melatonin as a natural ally against oxidative stress: a physicochemical examination," Journal of Pineal Research, vol. 51, no. 1, pp. 1-16, 2011.

[4] C. F. Chen, D. Wang, R. J. Reiter, and D. Y. Yeh, "Oral melatonin attenuates lung inflammation and airway hyperreactivity induced by inhalation of aerosolized pancreatic fluid in rats," Journal of Pineal Research, vol. 50, no. 1, pp. 46-53, 2011.

[5] K. Manda, M. Ueno, and K. Anzai, "AFMK, a melatonin metabolite, attenuates X-ray-induced oxidative damage to DNA, proteins and lipids in mice," Journal of Pineal Research, vol. 42, no. 4, pp. 386-393, 2007.

[6] R. Hardeland, D. Tan, and R. J. Reiter, "Kynuramines, metabolites of melatonin and other indoles: the resurrection of an almost forgotten class of biogenic amines," Journal of Pineal Research, vol. 47, no. 2, pp. 109-126, 2009.

[7] X. J. Lin, G. P. Mei, J. Liu et al., "Therapeutic effects of melatonin on heatstroke-induced multiple organ dysfunction syndrome in rats," Journal of Pineal Research, vol. 50, no. 4, pp. 436-444, 2011.

[8] W. S. Wu, M. T. Chou, C. M. Chao et al., "Melatonin reduces acute lung inflammation, edema, and hemorrhage in heatstroke rats," Acta Pharmacologica Sinica, vol. 33, no. 6, pp. 775-782, 2012.

[9] S. H. Chen, M. T. Lin, and C. P. Chang, "Ischemic and oxidative damage to the hypothalamus may be responsible for heat shock," Current Neupharmacology, vol. 11, no. 2, pp. 129-140, 2013. 
[10] S. Chatterjee, S. Premachandran, R. S. Bagewadikar, S. Bhattacharya, S. Chattopadhyay, and T. B. Poduval, "Arginine metabolic pathways determine its therapeutic benefit in experimental heatstroke: role of Th1/Th2 cytokine balance," Nitric Oxide, vol. 15, no. 4, pp. 408-416, 2006.

[11] S. Chatterjee, S. Premachandran, D. Sharma, R. S. Bagewadikar, and T. B. Poduval, "Therapeutic treatment with L-arginine rescues mice from heat stroke-induced death: physiological and molecular mechanisms," Shock, vol. 24, no. 4, pp. 341-347, 2005.

[12] Z. C. Chen, W. S. Wu, M. T. Lin, and C. C. Hsu, "Protective effect of transgenic expression of porcine heat shock protein 70 on hypothalamic ischemic and oxidative damage in a mouse model of heatstroke," BMC Neuroscience, vol. 10, p. 111, 2009.

[13] E. Crespo, M. Macías, D. Pozo et al., "Melatonin inhibits expression of the inducible NO synthase II in liver and lung and prevents endotoxemia in lipopolysaccharide-induced multiple organ dysfunction syndrome in rats," FASEB Journal, vol. 13, no. 12, pp. 1537-1546, 1999.

[14] C. C. Wu, C. W. Chiao, G. Hsiao, A. Chen, and M. H. Yen, "Melatonin prevents endotoxin-induced circulatory failure in rats," Journal of Pineal Research, vol. 30, no. 3, pp. 147-156, 2001.

[15] H. Togashi, K. Mori, K. Ueno et al., "Consecutive evaluation of nitric oxide production after transient cerebral ischemia in the rat hippocampus using in vivo brain microdialysis," Neuroscience Letters, vol. 240, no. 1, pp. 53-57, 1998.

[16] H. T. Hassoun, R. A. Kozar, B. C. Kone, H. J. Safi, and F. A. Moore, "Intraischemic hypothermia differentially modulates oxidative stress proteins during mesenteric ischemia/reperfusion," Surgery, vol. 132, no. 2, pp. 369-376, 2002.

[17] J. L. Wang, D. S. Ke, and M. T. Lin, "Heat shock pretreatment may protect against heatstroke-induced circulatory shock and cerebral ischemia by reducing oxidative stress and energy depletion," Shock, vol. 23, no. 2, pp. 161-167, 2005.

[18] F. Tietze, "Enzymic method for quantitative determination of nanogram amounts of total and oxidized glutathione: applications to mammalian blood and other tissues," Analytical Biochemistry, vol. 27, no. 3, pp. 502-522, 1969.

[19] O. W. Griffith, "Determination of glutathione and glutathione disulfide using glutathione reductase and 2-vinylpyridine," Analytical Biochemistry, vol. 106, no. 1, pp. 207-212, 1980.

[20] K. M. Mullane, R. Kraemer, and B. Smith, "Myeloperoxidase activity as a quantitative assessment of neutrophil infiltration into ischemic myocardium," Journal of Pharmacological Methods, vol. 14, no. 3, pp. 157-167, 1985.

[21] D. Wolf, J. Schümann, K. Koerber et al., "Low-molecular-weight hyaluronic acid induces nuclear factor $\kappa \mathrm{B}$-dependent resistance against tumor necrosis factor $\alpha$-mediated liver injury in mice," Hepatology, vol. 34, no. 3, pp. 535-547, 2001.

[22] L. R. Leon, M. D. Blaha, and D. A. DuBose, "Time course of cytokine, corticosterone, and tissue injury responses in mice during heat strain recovery," Journal of Applied Physiology, vol. 100, no. 4, pp. 1400-1409, 2006.

[23] N. Nunn, M. Womack, C. Dart, and R. Barrett-Jolley, "Function and pharmacology of spinally-projecting sympathetic preautonomic neurones in the paraventricular nucleus of the hypothalamus," Current Neuropharmacology, vol. 9, no. 2, pp. 262-277, 2011.

[24] B. S. McEwen, "Stressed or stressed out: what is the difference?" Journal of Psychiatry and Neuroscience, vol. 30, no. 5, pp. 315$318,2005$.
[25] L. C. Joo, R. Klein, N. C. Owens, M. Mathai, M. McKinley, and E. Badoer, "Activation of spinally projecting and nitrergic neurons in the PVN following heat exposure," American Journal of Physiology, vol. 291, no. 1, pp. R91-R101, 2006.

[26] H. J. Tsay, H. Y. Li, C. H. Lin, Y. Yang, J. Yeh, and M. Lin, "Heatstroke induces c-fos expression in the rat hypothalamus," Neuroscience Letters, vol. 262, no. 1, pp. 41-44, 1999.

[27] M. Cure, "Plasma corticosterone response in continuous versus discontinuous chronic heat exposure in rat," Physiology and Behavior, vol. 45, no. 6, pp. 1117-1122, 1989.

[28] J. Djordjević, G. Cvijić, and V. Davidović, "Different activation of ACTH and corticosterone release in response to various stressors in rats," Physiological Research, vol. 52, no. 1, pp. 6772, 2003.

[29] V. Michel, A. Peinnequin, A. Alonso, A. Buguet, R. Cespuglio, and F. Canini, "Decreased heat tolerance is associated with hypothalamo-pituitary-adrenocortical axis impairment," Neuroscience, vol. 147, no. 2, pp. 522-531, 2007.

[30] N. Malamud, W. Haymaker, and R. P. Custer, "Heat stroke," Military Surgery, vol. 99, no. 5, pp. 397-449, 1946.

[31] E. Gitto, M. Karbownik, R. J. Reiter et al., "Effects of melatonin treatment in septic newborns," Pediatric Research, vol. 50, no. 6, pp. 756-760, 2001.

[32] R. Hardeland, C. Backhaus, and A. Fadavi, "Reactions of the $\mathrm{NO}$ redox forms $\mathrm{NO}+{ }^{\circ} \mathrm{NO}$ and $\mathrm{HNO}$ (protonated $\mathrm{NO}-$ ) with the melatonin metabolite N1-acetyl-5-methoxykynuramine," Journal of Pineal Research, vol. 43, no. 4, pp. 382-388, 2007.

[33] M. Jou, T. Peng, L. Hsu et al., "Visualization of melatonin's multiple mitochondrial levels of protection against mitochondrial $\mathrm{Ca} 2+-$-mediated permeability transition and beyond in rat brain astrocytes," Journal of Pineal Research, vol. 48, no. 1, pp. 20-38, 2010.

[34] D. Mukherjee, S. G. Roy, A. Bandyopadhyay et al., "Melatonin protects against isoproterenol-induced myocardial injury in the rat: antioxidative mechanisms," Journal of Pineal Research, vol. 48, no. 3, pp. 251-262, 2010.

[35] G. Paradies, G. Petrosillo, V. Paradies, R. J. Reiter, and F. M. Ruggiero, "Melatonin, cardiolipin and mitochondrial bioenergetics in health and disease," Journal of Pineal Research, vol. 48, no. 4, pp. 297-310, 2010.

[36] J. Y. Wu, M. Y. Tsou, T. H. Chen, S. J. Chen, C. M. Tsao, and C. $\mathrm{C}$. Wu, "Therapeutic effects of melatonin on peritonitis-induced septic shock with multiple organ dysfunction syndrome in rats," Journal of Pineal Research, vol. 45, no. 1, pp. 106-116, 2008.

[37] J. A. Morecroft and L. Spitz, "The role of inflammatory mediators in necrotizing enterocolitis," Seminars in Neonatology, vol. 2, no. 4, pp. 273-280, 1997.

[38] J. Boldt, M. Wollbruck, D. Kuhn, L. C. Linke, and G. Hempelmann, "Do plasma levels of circulating soluble adhesion molecules differ between surviving and nonsurviving critically ill patients?” Chest, vol. 107, no. 3, pp. 787-792, 1995.

[39] G. S. Kansas, "Selectins and their ligands: current concepts and controversies," Blood, vol. 88, no. 9, pp. 3259-3287, 1996.

[40] K. Goda, T. Tanaka, M. Monden, and M. Miyasaka, "Characterization of an apparently conserved epitope in E- and P-selectin identified by dual-specific monoclonal antibodies," European Journal of Immunology, vol. 29, no. 5, pp. 1551-1560, 1999.

[41] A. Bouchama and J. P. Knochel, "Medical progress: heat stroke," New England Journal of Medicine, vol. 346, no. 25, pp. 1978-1988, 2002. 
[42] W. S. Liu, C. T. Chen, N. H. Foo et al., "Human umbilical cord blood cells protect against hypothalamic apoptosis and systemic inflammation response during heatstroke in rats," Pediatrics and Neonatology, vol. 50, no. 5, pp. 208-216, 2009.

[43] T. J. Standiford, R. M. Strieter, N. W. Lukacs, and S. L. Kunkel, "Neutralization of IL-10 increases lethality in endotoxemia: cooperative effects of macrophage inflammatory protein-2 and tumor necrosis factor," Journal of Immunology, vol. 155, no. 4, pp. 2222-2229, 1995.

[44] J. Bonior, J. Jaworek, S. J. Konturek, and W. W. Pawlik, "Increase of heat shock protein gene expression by melatonin in AR42J cells," Journal of Physiology and Pharmacology, vol. 56, no. 3, pp. 471-481, 2005.

[45] J. Cabrera, J. Quintana, R. J. Reiter, J. Loro, F. Cabrera, and F. Estévez, "Melatonin prevents apoptosis and enhances HSP27 mRNA expression induced by heat shock in HL-60 cells: possible involvement of the MT2 receptor," Journal of Pineal Research, vol. 35, no. 4, pp. 231-238, 2003. 


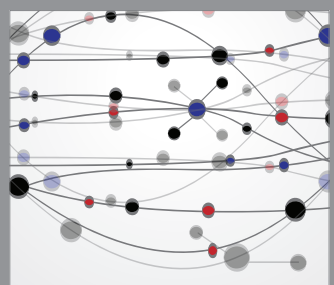

The Scientific World Journal
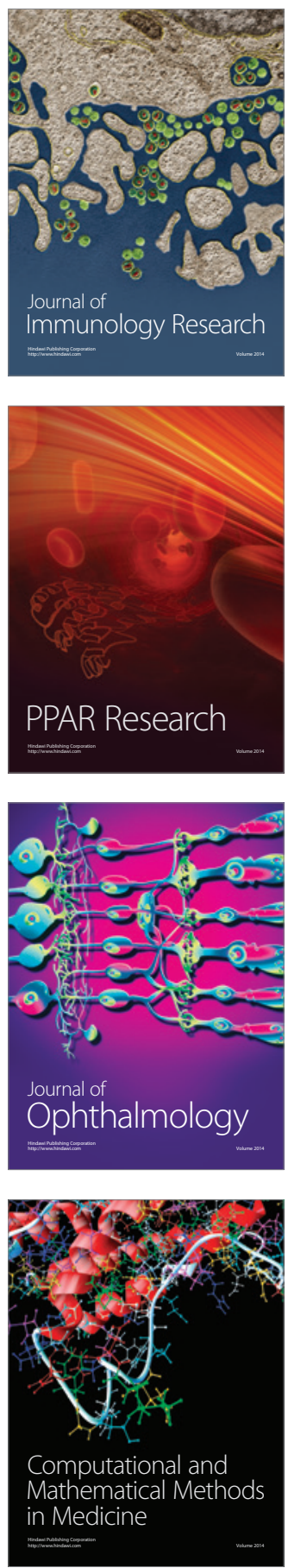

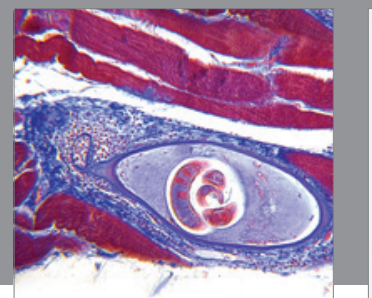

Gastroenterology

Research and Practice
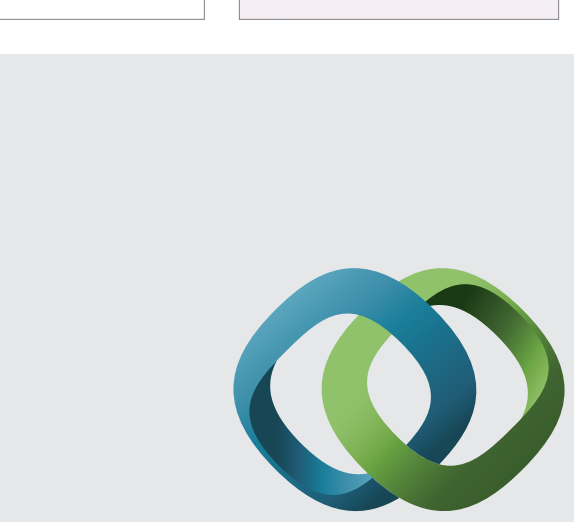

\section{Hindawi}

Submit your manuscripts at

http://www.hindawi.com
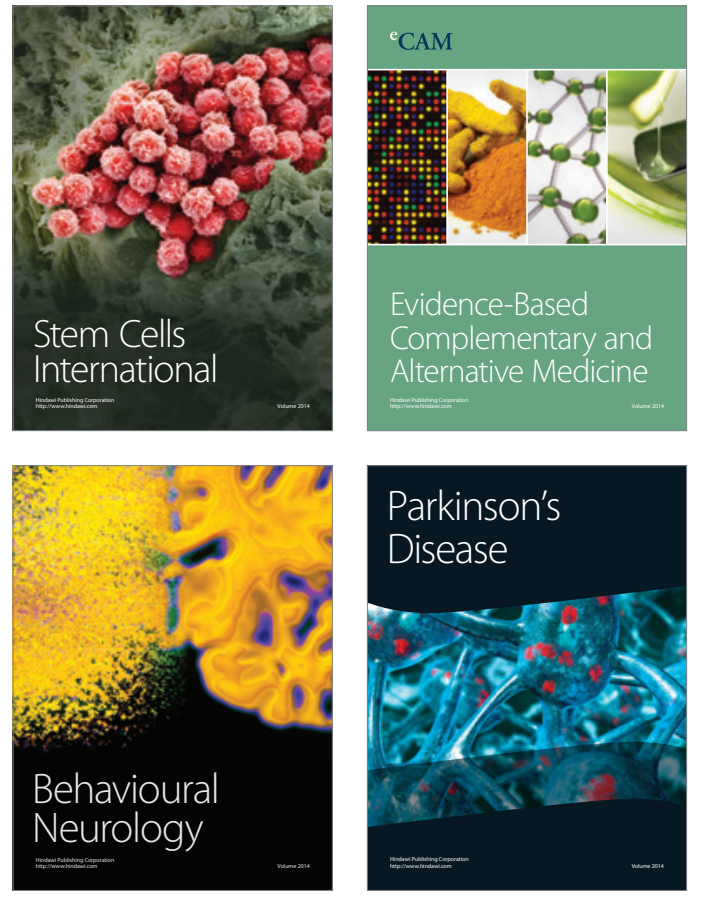
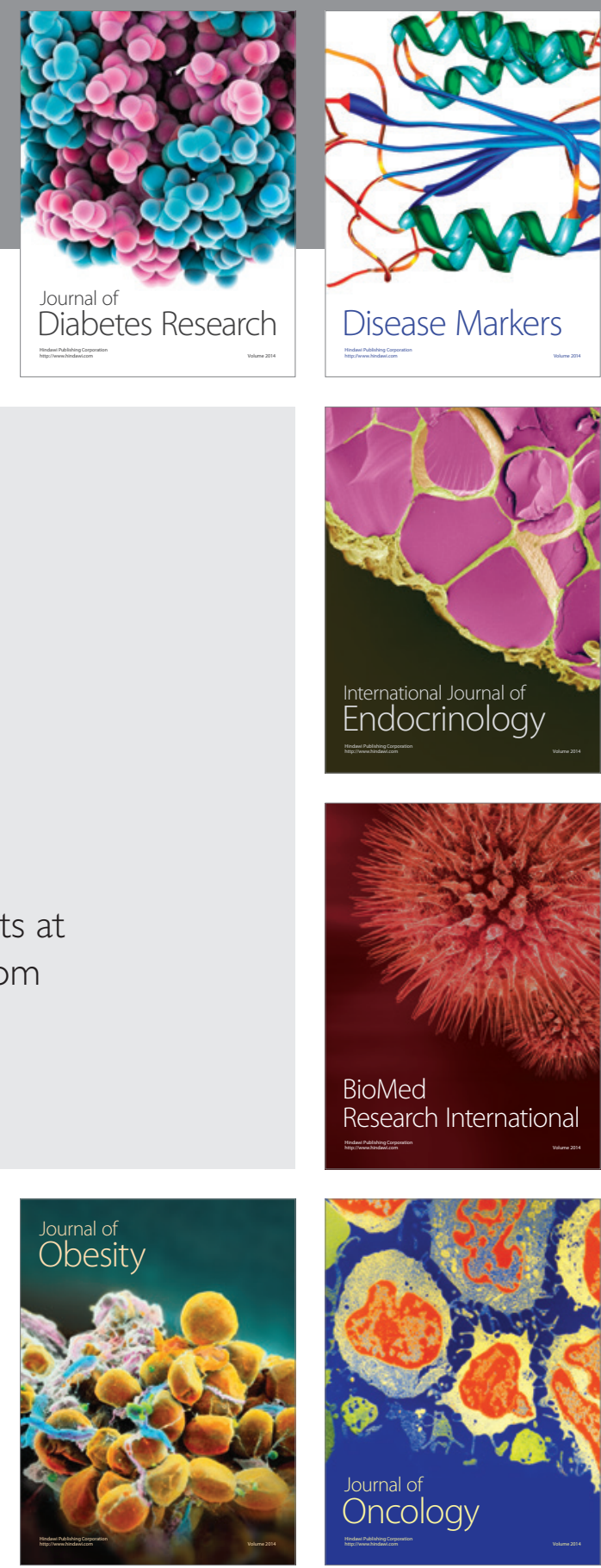

Disease Markers
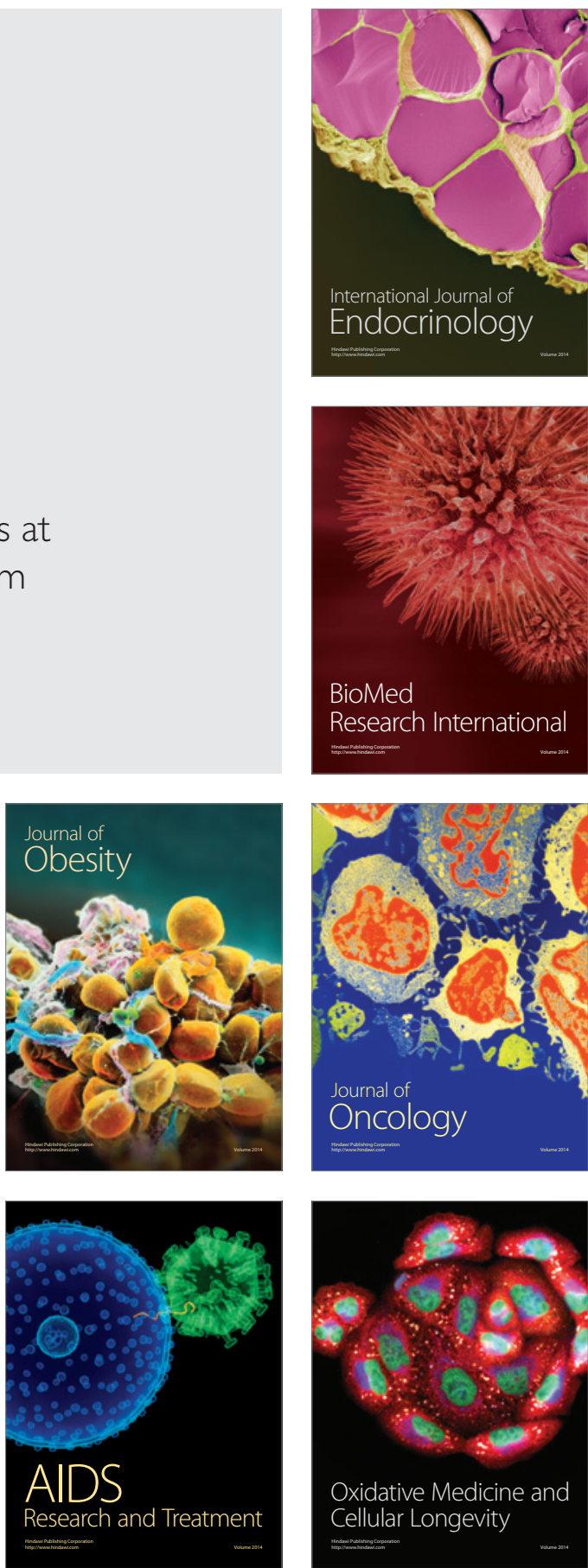